\begin{tabular}{|l|l|l||}
\hline \multicolumn{2}{|c|}{ PublisherInfo } \\
\hline \hline PublisherName & $:$ & BioMed Central \\
\hline \hline PublisherLocation & $:$ & London \\
\hline \hline PublisherImprintName & $:$ & BioMed Central \\
\hline \hline
\end{tabular}

\title{
Precompiled codon-usage tables
}

\begin{tabular}{|c|c|c|}
\hline \multicolumn{3}{|c|}{ ArticleInfo } \\
\hline ArticleID & : & 3615 \\
\hline ArticleDOI & : & 10.1186/gb-2000-1-1-reports241 \\
\hline ArticleCitationID & : & reports 241 \\
\hline ArticleSequenceNumber & : & 106 \\
\hline ArticleCategory & : & Web report \\
\hline ArticleFirstPage & : & 1 \\
\hline ArticleLastPage & : & 4 \\
\hline ArticleHistory & : & $\begin{array}{ll}\text { RegistrationDate } & : 2000-2-29 \\
\text { Received } & : 2000-2-29 \\
\text { OnlineDate } & : 2000-4-27\end{array}$ \\
\hline ArticleCopyright & : & BioMed Central Ltd2000 \\
\hline ArticleGrants & : & \\
\hline ArticleContext & & 130591111 \\
\hline
\end{tabular}




\section{Todd Richmond}

\section{Abstract}

Given the variety of codon usage by different organisms and organelles, this centralized codonusage resource is invaluable.

\section{Content}

Given the variety of codon usage by different organisms and organelles, this centralized codon-usage resource is invaluable. First, it enables determination of codon usage for any organism or virus for which there is DNA sequence information in GenBank. On inputting the Latin name of the organism (or the virus) the database will provide a codon-usage table, in standard format, using any of 14 genetic codes (standard, vertebrate mitochondrial, yeast mitochondrial and so on). The website will also generate a codon-usage table from any DNA sequence. This is useful for those attempting to express proteins in heterologous systems, who may need to adjust the codon usage of their constructs to suit the target organism. There is an alphabetical list of all of the organisms included in the site, with separate entries for chloroplasts and mitochondria.

\section{Navigation}

Use of the site is straightforward. The homepage has a dialog box into which the Latin name of the organism is typed. The search apparently supports standard regular expressions, although this implementation appears to be partially broken. If you cannot remember how to spell Saccharomyces cerevisiae, you can search for sacc* to pull up a list of organisms with 'sacc' in their name (including, for instance, Zygosaccharomyces cidri). If you only know the common name, however, you are out of luck. The NCBI taxonomy browser will find the Latin name, however, and you can then return to the Codon Usage Database to complete your search. On inputting the name, a standard codon table is produced and a preferred genetic code can be chosen. There is also the option to output the codon table in Genetics Computer Group (GCG) format, which is useful for many DNA analysis programs. To generate a codon table from a particular DNA sequence, choose the 'Countcodon' option on the homepage, cut and paste the DNA sequence into the form provided and choose the appropriate genetic code. 


\title{
Reporter's comments
}

\section{Timeliness}

The site was last updated on 15 August 1999.

\section{Best feature}

This site is tremendously easy to use. Type in the organism, and click, click, click, you have a nicely formatted codon-usage table.

\section{Wish list}

Why not update the database after each GenBank release? The site is currently based on GenBank Release 113; the latest is Release 116, which contains at least a million more sequences than Release 113. Although most researchers will know the scientific name of their organism of interest, the inability to search using common names is a hindrance; at least provide a link to the NCBI taxonomy browser. It would be helpful if searching were case-insensitive by default. Providing the output on a page that is easily saved and does not have to be edited would also be an improvement; as it is, a bunch of extraneous form text is included with the table when saved.

\section{Related websites}

Although there are various sites that contain the codon-usage tables for a handful of species, mostly model organisms, this is the only comprehensive codon-usage resource available on the internet at present.

\section{Table of links}

\author{
Codon Usage Database
}

GenBank 
NCBI taxonomy browser

\section{References}

1. Codon Usage Database.

This PDF file was created after publication. 